\title{
LIFE SKILL EDUCATION \\ AND IT'S IMPLEMENTATION IN STUDY PROGRAMS ISLAMIC RELIGIOUS EDUCATION
}

\author{
Amirudin', Iqbal Amar Muzaki² \\ 1,2 University of Singaperbangsa Karawang, Karawang, Indonesia \\ Email : 1amirudin@staff.unsika.ac.id, 2iqbalamar.muzaki@fai.unsika.ac.id
}

\section{DOI : 10.30829/tar.v26i2.485}

Accepted: September 5th, 2019. Approved: December 19th, 2019. Published: December 25th, 2019

\begin{abstract}
The era of globalization requires humans to have more expertise to work and be competitive. These pressures lead to issues of productivity, efficiency, level of competition, which demand increased performance and quality. In addition to the problem of educated unemployment, it turns out there are still many schools or institutions that have not yet implemented life skills education, so graduates do not have more expertise to develop. The aim of this research was to know Islamic Education Study Program Faculty of Islamic Religion life skills education and it's implementation. This type of research is conducted using a mixed methodology. Data collected from 130 respondents by using questionnaire and interview. The result is life skill education which most followed by Islamic Education Study Program Faculty of Islamic Religion students is the education of reading the Qur'an, practice recitations, practice of worship, basic training of student leadership, and training of preacher and preacher cadres.
\end{abstract}

Keywords: Era of Globalization, Islamic Religious Education, Life Skills 


\section{INTRODUCTION}

Education is a series of interaction activities aimed at, between adult humans and students face to face or by using the media in order to provide assistance to the development of students as a whole. In a sense, in order to develop its potential to the fullest, in order to become an adult human being. Potential here is physical potential, emotional, social, attitudes, morals, knowledge and skills (Langford \& Badeau, 2015: 82). In the Qur'an education is also highly emphasized, so that education itself has the same priority as jihad in the way of Allah, as Allah SWT said:

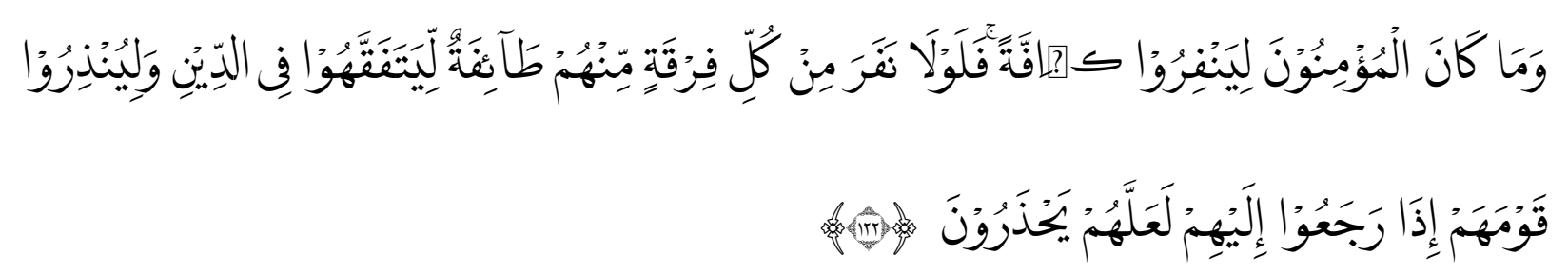

Meaning: "It is not fitting for all believers to go (to the battlefield). Why not go away from each group among them a number of people to deepen their knowledge of religion and to warn their people when they return to them, so that they can take care of themselves." (Indonesian Ministry of Religion, 2006: 277).

Meanwhile, according to Marimba (1987: 19) that education is guidance or leadership consciously by an educator on the physical and spiritual development of students towards the formation of the main personality. Education is indeed very useful for every individual. So, education is a process of teaching and learning that familiarizes citizens as early as possible to explore, understand, and practice all the values agreed upon as commendable and desirable, and useful for life and development of personal, community, nation and state.

Education is very important for every child, influenced and influential on the environment. The most important environment is the family, how parents (especially mothers) guide their children to be ready to face life in the present and the future (Prajapati, Sharma, \& Sharma, 2017: 2). A child's life skills education must be guided so that they do not deviate from religious norms that are in accordance with the Qur'an, and also capable of producing young people who faithful, creative, innovative and responsible (Satori, 2002: 25).

Continuing education and character development are a duty for families, communities and governments, preparing a formidable generation of Muslims. All of that 
are the hope of all parents accordance with the Al-Qur'an. Every Muslim, both as an individual and as a community, must strive to create a quality generation in all aspects of human life. One of the words of Allah SWT which requires that every people do not leave behind them a generation that weak and helpless and has no competitiveness in life.

Some people, even parents, think that having a smart children is enough. In addition, a child who has graduated or graduated from a university with a certain academic degree has not been able to guarantee a more promising future for a child's life. Such thinking will certainly find a point of relevance in time. However, in certain situations and conditions it may be that the promising promises of the academic degree become less relevant, even the wider community is no longer trusted. Along with the increasing number of unemployed due to educational factors, and the rise of corruption cases that can not be separated from the bureaucrats who have many degrees, bachelor's, master's, doctoral, and even professors. The role and function of education in this context will certainly get a lawsuit from many groups, for example why corrupt practices are actually carried out by smart and smart people. This fact is indeed very sad, even this nation is often connoted as a nation that is very creative in terms of corruption, from the lowest layer to the top.

Therefore, skills, creativity and independence are three very important points for every student to have so he can be capable of dealing with the reality of his life, creative in providing solutions to existing problems. Life skills oriented education is education to shape character and ethos, besides education like this aims to actualize the potential of students so that it can be used to solve the problems that are being faced. As a result of education, learning that leads to life skills, the main principle is the process of involvement of all or most of the students' potentials (physical and non-physical) and their meaning for themselves in the future (Murthy, 2016: 60).

While there are a number of studies identifying life skill education, such as Parvathy \& Pillai (2015) and Weichold \& Blumenthal (2016) in India for young adolescents, Daisy \& Radakrishnan (2018) for the urban adolescents in Ghaziabad district of UP, Dhingra \& Chauhan (2017) in five Zones of Delhi Municipal council, Pradeep, Arvind, Ramaiah, S. et al. (2019) for college going youth in the state of Karnataka in India. In Indonesia, there are number of studies, such as Wahyuni \& Indrasari (2017) in Bondowoso for senior high school students, Naelasari (2018) in Jombang for boarding school student, Fauzi, Meilya, \& Siregar (2017) in Yogyakarta for boarding school student, 
Said \& Yusof (2015) in junior and senior high schools in Indonesia, Noor (2015) for boarding school student in Bandung, Juhji, Khaeroni, Masto'ah, \& Habudin (2019) for undergraduate student Primary Teacher Education in Banten. But the research about life skill education in Indonesia for study programs islamic religious education student still very few. So, the researcher will research life skill education and it's implementation in programs islamic religious education.

\section{METHOD}

\section{Type of Research}

This type of research is conducted using a mixed methodology. Expected by the mixed method can produce more comprehensive facts in this study. This Mixed Method is a method that combines qualitative and quantitative approaches in terms of methodology (as in the data collection stage), and mixed model studies combine two approaches in all stages of the research process (Tashakkori \& Teddlie, 2010: 8). Mixed Method is also referred to as a methodology that provides philosophical assumptions in showing direction or giving instructions on how to collect data and analyze data and the integration of quantitative and qualitative approaches through several phases of the research process.

The research specification used is descriptive analysis which aims to make a description or description of the facts, the characteristics and the relationship between the phenomena investigated (Nasir, 2003: 63). This descriptive study is research that is not intended to test certain hypotheses but only describes what they are about a variable, symptom or condition (Arikunto, 2016: 310). Data collection by describing as it is, is not accompanied by reviews or views or analysis from the author (Bachtiar, 1997: 60).

\section{Population and sample}

The population in this study were all students of the Islamic Religious Education Study Program Faculty of Islamic Religion which consisted of 520 people. Researchers took $25 \%$ of the total population of 520 respondents as sample. So the sample was 130 respondents.

Sample is chosen by using a random sample, where researchers mix subjects in the population so that all populations are considered equal. Thus the researcher gives equal 
rights to each subject to obtain the opportunity to be selected as a sample. So in sampling all students have the same right to be sampled.

\section{Data Sources}

Sources of data in this study were divided into two, namely primary data and secondary data but in this study only used primary data. According to Moleong (2017: 157) the main data sources in qualitative research are words and actions, the rest are additional data such as documents and others. Primary data, namely data obtained directly from research subjects using data collection tools directly on the object as a source of information sought (Sukmadinata, 2013: 93). In this case the writer directly examines the students of the Islamic Faculty of Islamic Studies (FAI) UNSIKA to get data by distributing questionnaires and interviews.

\section{Data Collection Techniques}

To obtain the data needed in research, researchers use data collection techniques as follows:

a. Questionnaire (Questionnaire)

It is a method of collecting data using a number of written questions that are used to obtain information from the respondent in terms of reports about his personality, or things he knows (Arikunto, 2016: 151). The questionnaire method is used to obtain data and explore data about something related to the perception of PAI Study Program students about Life skill education.

b. Interview (Interview)

Interview is the most sociological research technique because of its shape which comes from verbal interaction between researchers and respondents (Black, 2009: 305). Interviews are conducted through conversations with a specific purpose carried out by two parties, namely the interviewer who asks the question and the interviewer who gives the answer to that question. In-formal conversation refers to the tendency of a very open nature so that the interview is really similar to a conversation (Pawito, 2007: 132). In this interview the researcher used a structured interview which is an interview consisting of a list of questions that have been planned and have been prepared previously. All respondents received the same question, in words and in uniform order. 
As for the informants in this study were PAI Study Program students from class of 2013, 2014, 2015 and 2016. In this interview the researchers interviewed 10 informants who were selected based on a random method from existing respondents. Interviews were conducted to complete the data obtained from the results of the questionnaire and to clarify the desired results.

\section{Data Analysis Techniques}

Data analysis technique is the process of systematically searching and compiling data obtained from interviews, field notes, and documentation, by organizing data into categories, describing into units, synthesizing, organizing into patterns, choosing what is important and what will be learned, and make conclusions so that they are easily understood by themselves and others. For the purposes of data analysis, researchers use a type of descriptive analysis research, namely research that intends to understand the phenomena about what is experienced by research subjects such as behavior, perception, motivation, action (Moleong, 2010: 4).

In this study the authors completed by going through several stages of data processing, namely as follows: First, the authors conducted a study by distributing questionnaires to respondents. After the data is collected the researchers group by sex, and group again based on a list of questions in the questionnaire. Second, process and analyze data so that conclusions can be drawn. Third, the writer collected data by interviewing a number of PAI Study Program students, then analyzing the results of the interview. Fourth, interpret the results of the analysis both from questionnaires and interviews, so that students can find out perceptions of life skill education material. Fifth, the data that has been collected so that it is easy to analyze and conclude, the authors use analysis that produces descriptive analysis. The process of data analysis uses inductive thinking patterns, namely the process of processing data from specific matters and obtained from respondents then in general conclusions are drawn.

\section{Data Interpretation}

After calculating the percentage, then the researcher interprets the data, this is intended to determine the condition or description of each aspect studied based on the responses of respondents. To determine the percentage, a simple calculation using steps: (a) Determine the expected value (NH), this value can be known by multiplying the 
number of question items with the highest score, (b) Calculating the score (NS), this value is the actual average value obtained from the results of the study, (c) Determine the categorical formula, using the following formula: $\mathrm{P}=(\mathrm{NS} / \mathrm{NH}) \times 100 \%$, which $\mathrm{P}=$ Percentage (average value), $\mathrm{NS}=$ Score Value, $\mathrm{NH}=$ Expectation Value, and $100 \%=$ Fixed number (constant)

\section{RESULTS AND DISCUSSION}

\section{Description of Life Skill Education for students of the Faculty of Islamic Religion (FAI) UNSIKA}

Life skill education is one of the focuses of analysis in the development of educational curriculum that emphasizes life skills or work. Life skills have a broader meaning of employability skills and vocational skills. Both are part of the life skill program. Brolin (1989: 35) explains that life skill constitutes a continuum of knowledge and aptitude that is necessary for a person to function and to avoild intrupptions of employment experience. Thus life skills can be expressed as life skills. The term life skill, not merely has a certain vocational ability, but it must have its basic functional support capabilities such as reading, writing, calculating, formulating and solving problems, managing resources, working in teams, work, use technology (Satori, 2002: 37).

Life skill education program is an education that can provide practical skills, can be used, related to the needs of the job market, business opportunities and economic potential or industry in the community. This life skill has a wide range, it interacts with knowledge that is believed to be an essential ingredient for a more independent life. Another notion states that life skill refers to the wide range of abilities that a person needs to pursue to have a successful, happy and dignified life in society. Life skill is the ability to communicate effectively, develop cooperation skills, perform the role of responsible citizens, have the readiness and skills to work, and have the character and ethics to enter the workforce. Elucidation of article 26 paragraph 3 of Law No.20 of 2003 on National Education System states that life skill education is "education that provides personal, social, intellectual, and vocational skills for work or independent business".

Ministry of National Education divides life skill into four types, namely:

a. Personal skills that include selfawareness and social skills. 
Personal skills, such as decisionmaking, problem-solving skills are the main ones in determining a person's growth. Decision-making and ability to solve problems can pursue many shortcomings. For example, a person will not know how to drive a bus to work, but the ability to solve problems can help him out and he must meet someone who can convince him to get a chance to work every day. Self-knowledge is basically a selfappreciation as a creature of God Almighty, a member of society and citizen, and aware and grateful for the advantages and disadvantages possessed, as well as making it as a capital in improving himself as an individual who benefits himself and his environment. Rational thinking skills include, among other things: the ability to dig and find information, information processing skills and make decisions and creative problem-solving skills. To educate the public, it needs encouragement from outside parties or create a certain condition is needed to develop the potential that exists in each individual, in the sense that the skills given must be based on learning skills (Hidayanto, 2002: 562).

b. Social skills or interpersonal skills

Social skills or interpersonal skills include: communication skills with empathy, and cooperative skills. Empathy is understanding attitude and the art of two-way communication. It needs to be emphasized because it means communicating is not just delivering message but the content and arrival of the message should be accompanied by a good impression that will grow harmonious relationship. Social skills can include 46 communication skills, anger management, and conflict solutions. The situation of having friends and sharing with co-workers and roommates mostly rely on the practice of skills to help someone more socially competent. The two life skills described above are usually referred to as general life skills. This general life skill is required by anyone, whether they are working, or unemployed, or those who are studying. In addition, it needs a noble character, meaning that all the skills must be imbued by noble character.

c. Academic skills 
Academic skills are also called the ability of scientific thinking which is basically the development of rational thinking skills which are still general. Academic skills are more directed to academic / scientific activities. Academic skills include the ability to identify variables and explain their relationship to a particular phenomenon, to formulate hypotheses on a sequence of events, and to design and conduct research to prove an idea or curiosity.

d. Vocational skills

Vocational skills mean skills that are associated with a particular field of work in society. It should be realized that in real life, between general life skill and specific skill that is between self-knowing skills, rational thinking skills, social skills, and academic skills and vocational skills does not function separately, or exclusively. The thing that happens is the fusion of these skills, so it blends into an individual action involving the physical, mental, emotional and intellectual aspects. The degree of quality of individual action is in many ways influenced by the quality of maturity of the various aspects of the support mentioned above. Academic skills and vocational skills belong to a specific life skill. This skill is needed for someone to deal with a particular field problem.

The purpose of Life Skill Education by Dhingra \& Chauhan (2017: 208), are as follows: (1) Actualize the potential of learners so that it can be used to solve various problems in his life, (2) Provides a broad insight into career development, (3) Supplied with basic exercises on values related to everyday life, (4) Provide opportunities for schools to develop flexible learning in accordance with the principles of broad-based education, (5) Optimizing the use of resources within the school and community environment in accordance with the principles of schoolbased management.

Meanwhile, Parvathy \& Pillai (2015: 790) suggests that the general purpose of life skill education (life skill) is to improve skills, knowledge and attitudes of people in the field of work or a particular business in accordance with their talents and interests so they have the provision of the ability to work or to strive independently. Improve the quality of his life. While the specific purpose is to provide life skills education services to citizens to learn to have the skills, knowledge, and attitudes needed in entering the world of work, both selfemployed (self-employed) and or working in a production / service company with increasingly feasible income to meet the needs of his life, have a high motivation and 
work ethic and can produce works that are superior and able to compete in the global market.

Benefits of Life Skill according to MoNE (2003: 9-10) are namely: (1) For citizens to learn to have the skills, knowledge, attitude as a provision to be able to work or selfemployed, have income that can support themselves and their families, transmit / give perceived useful ability to others, improve the quality of life, family and environment, (2) For people to reduce unemployment, create jobs for others, reduce social inequalities, (3) For the government to improve the quality of human resources in the region, to prevent urbanization, to grow business community economic activities, to suppress social vulnerability.

Life Skills education provides students with personal benefits and social benefits for the community. For learners, life skill education can improve the quality of thinking. Improving the quality can increase the choices in the life of the individual, such as career, income, physical and spiritual health, opportunities, self-development, competitive ability, and personal well-being. For the community, life skills education can improve the advanced life with indicators of: social welfare improvement, and community development that is harmoniously able to integrate religious values, theories, solidarity, and the economy

To know the life skill learning model can be seen through the way of learning to develop life skills such as:

a) Provide questions / tasks that encourage students to do / think. The types of questions asked or the tasks assigned by the teacher are very influential on the development of students' thinking skills. The question / task is not just to focus students on the activities, but also to explore students' learning potential. Questions or tasks that trigger students to think analytically, evaluatively, and creatively can train students to be critical and be creative thinkers.

b) Provide questions / tasks that contain problem solving. High-level questions / tasks can be used as a prefix to practice problem-solving. High-level questions / tasks that meet the criteria as a problem are used as starting points to follow the troubleshooting steps. Problem solving is one of the academic skills that needs to be developed continuously in order to become a student habit. This problem solving is essential to help students acquire the analytical, synthetic, scientific, and technological skills necessary to achieve success in formal and workplace education institutions. 
c) Implement Cooperative Learning. Cooperative learning is one of the efforts to realize active, creative, effective and fun learning. Cooperative learning provides an opportunity for students to interact with each other. Students who explain each other's understanding of a concept to their friends are actually experiencing a very effective learning process that can provide learning results that are far more leverage than if he listened to teacher explanations. Cooperative learning provides an opportunity for students to develop some life skills called communication skills and 48 cooperative skills. This skill has an important role in real life.

The application of cooperative learning will yield effective results when considering the following two core principles. All members in the group are interdependent on other members in achieving group goals, such as completing the task of the teacher. The existence of personal responsibility (individual accountability). Here each member of the group must have an active contribution in working together. Therefore it is important for us to learn some form of cooperative learning and actual enrollment so that misunderstandings about group / cooperative learning in learning can be avoided. The study was conducted at the Islamic Religious Education Study Program Faculty of Islamic Religion from 2013, 2014, 2015 and 2016 consisting of 520 populations, and 130 respondents (25\%) were sampled. The table shows that 130 students (25\%) of the total.

Table 1. Percentage of life skill education followed by students

PAI Study Program Faculty of Islamic Sciences UNSIKA

\begin{tabular}{|c|c|c|c|c|c|}
\hline Category & Total & $\%$ & Forms of activity & Total & $\%$ \\
\hline \multirow{8}{*}{$\begin{array}{l}\text { Following } \\
\text { life skills } \\
\text { education }\end{array}$} & \multirow{8}{*}{130} & \multirow{8}{*}{25} & Reading and writing the Qur'an & 130 & 100 \\
\hline & & & Tilawah practice & 130 & 100 \\
\hline & & & Pray practice & 130 & 100 \\
\hline & & & Preacher and preacher training cadres & 65 & 50 \\
\hline & & & Islamic Arts Training & 26 & 20 \\
\hline & & & Campus Da'wah Communication Forum & 33 & 25 \\
\hline & & & Student Boarding School & 65 & 50 \\
\hline & & & Basic Student Leadership Training & 130 & 100 \\
\hline
\end{tabular}


The population that is the subject of research follows life skill education. There is education in reading the Qur'an carried out by these 130 students (100\%); 130 people (100\%) students follow recitations; 130 people (100\%) follow the practice of Worship; 65 people (50\%) attended the preacher and preacher training cadres; 26 people (20\%) attended Islamic arts training; 33 people (25\%) took part in the campus Communication and Mission Forum activities; 65 people (50\%) always attend campus pesantren; and 130 people (100\%) took part in the basic training of student leadership.

\section{Implementation of Life Skill Education in the Islamic Education Study Program FAI UNSIKA}

Life skill-oriented education does not change the education system nor does it reduce education only as a skill exercise. Life skill-oriented education actually provides an opportunity for every student to increase their potential and provide opportunities to acquire skills / skills that can be used as a source of livelihood. In implementing educational policies that are oriented to life skills, the main focus of educational activities must be aimed at preparing students to have the skills to live and be able to take a life journey.

The implementation of life skills education implemented has taken into account the following matters: (a) Ability (life skills) that are relevant to the needs of students on campus, (b) Learning materials are learned according to students' interest in mastering their talents, (c) What facilities, tools, and learning resources need to be provided to support the ownership of the desired abilities. MoNE (2002) states that life skills include some basic abilities, namely: (a) Personal skills, which include: self-awareness skills and rational thinking skills, (b) Social skills, (c) Academic skills, and (d) Vocational skills.

Examples of implementation of life skills education in Islamic religious education study programs are Read Al Qur'an, Read Al Qur'an, Tilawah Practice, Preaching and Preachers cadre training, Campus Da'wah Communication Forum, Basic Student Leadership Training. Life skills education in these activities is highly needed by students because it places great emphasis on generic life skills, namely personal and social skills. Because personal and social life skills are an important foundation students have to cultivate other abilities that are fundamental. 


\section{The Future of Life Skill Education for Faculty of Islamic Students (FAI) UNSIKA}

The results showed that the life skill education that most students participated in was reading al-Qur'an, recitation practices, worship practices, basic training in student leadership, and training of preacher and preacher cadres. The implementation of life skills in the Faculty of Islamic Religion (FAI) Element basically does not change the existing education system, and does not reduce education as mere training, but this program places the position of the Faculty of Islamic Religion (FAI) as an educational institution that develops programs academics are in accordance with the mission of the Faculty of Islamic Religion (FAI) to prepare students to have good life skills that benefit society, the nation and their religion.

The Faculty of Islamic Religion (FAI) provides an opportunity for every student to increase his potential and even to provide opportunities for students to acquire skills that can be used as a source of livelihood later. Application (life skills) in the Faculty of Islamic Religion (FAI) is oriented towards mastering special skills, not intended to dictate universities or institutions, but only offers a variety of possibilities or menus that can be chosen according to the real situations and conditions of the campus both in terms of the whereabouts of students and the life of the surrounding community.

The function and purpose of life skills education (life skills) to be achieved by students themselves is to recognize the nature of themselves, the best potential and talents they have and try to be able to actualize all the potential possessed by students by expressing and expressing themselves fully in a way to become himself. The program of implementing life skills is inspired by the concept of link and mach, which means the relationship and equivalence or can be more termed with Dual System Education (PSG), which literally is adopted from the German language, link and mach, which means the perspective that education is an integral part from community life.

The purpose of implementing life skills education that is based on the link and mach principle here is to get the quality of human resources, especially those related to the quality of life skills, where the world of education as a provider of human resources, while the community as the party in need. 


\section{CONCLUSION}

Based on the questionnaire that was distributed, the students who took life skill education were more than half or as many as $68 \%$ ( 88 people). Most of them choose the program to read write the Qur'an, practice recitation, and practice of worship. In carrying out this life skill education, the main focus of the activity is aimed at preparing students to have life skills and be able to travel their future. The application of life skills in the Faculty of Islamic Religion (FAI) is oriented towards mastering special skills, not intended to dictate universities or institutions, but only offers a variety of possibilities or menus that can be selected according to the real situations and conditions of the campus both in terms of the presence of students and the lives of the surrounding community.

From the results of this study the authors suggest: (1) Parents to guide their children to be ready to face life in the present and the future because a child's life skills must be guided and directed so as not to deviate from religious norms in accordance with the Qur'an, in order to be able to produce young generations who are faithful, creative, innovative and responsible, (2) For students to be instilled and can improve the quality of life skills that have been implanted both in schools and the community environment, and (3) For the government must support and be able to provide the facilities needed for educational institutions that apply life skills education so that life skills education gives birth to generations which in turn can improve the welfare of themselves, society and can fight ignorance and poverty.

\section{REFERENCES}

Arikunto, Suharsimi. (2016). Prosedur penelitian: Suatu pendekatan praktik. Jakarta: Rineka Cipta.

Bachtiar, Wardi. (1997). Metodologi penelitian ilmu dakwah. Jakarta: Raja Grafindo Persada.

Black, J. A. \& Champion, D. J. (2009). Metode dan masalah penelitian sosial. Bandung: Refika Aditama.

Brolin, D.E. 1989. Life centered career education: A competency bassed approach. Reston VA: The Council for Exceptional Children.

Daisy, P.J. \& Radhakrishnan, Nair. (2018). An Exploratory Study On Life Skills Intervention And Its Impact On The Study Skills Among Young Adolescents. 
Amirudin, Iqbal Amar Muzaki / JURNAL TARBIYAH 26 (2) (2019) 278-293

International Journal of Innovations in Engineering and Technology (IJIET), 10(3), 14-20.

Dhingra, R. \& Chauhan, K.S. (2017). Assessment of life-skills of adolescents in relation to selected variables. International Journal of Scientific and Research Publications, 7(8), 201-212.

Fauzi, A., Meilya, I. R., \& Siregar, H. (2017). Pengelolaan pendidikan life skill di pondok pesantren Kabupaten Pandeglang. Jurnal Eksistensi Pendidikan Luar Sekolah, 2(2), 116-213.

Hafid, Anwar. (2013). Basic concepts of education. Bandung: Alfabeta.

Hidayanto, D. N. (2002). Keterampialan belajar vs belajar keterampilan. Jurnal Ilmu Pendidikan, 9(4), 557-569.

Indonesian Ministry of Religion. (2006). Al-Qur'an dan terjemahannya. Semarang: Toha Putra.

Marimba, Ahmad D. (1987). Pengantar filsafat pendidikan islam. Bandung: PT. AlMa'arif.

Ministry of National Education (MoNE). (2006). Development of life skills education models. Jakarta: Puskur Balitbang Depdiknas.

Moleong, Lexy J. (2017). Metode penelitian kualitatif. Bandung: Remaja Rosdakarya.

Murthy, Venkatesha. (2016). Issues, problems and possibilities of life skills education for school going adolescents. The International Journal of Indian Psychology, 3(3), 56-76.

Naelasari, D. (2018). Implementasi pendidikan life skill dalam pembentukan kemandirian santri. DAR EL-ILMI : Jurnal Studi Keagamaan, Pendidikan Dan Humaniora, 5(2), 179-199.

Nasir, Mohammad. (2003). Metode penelitian. Jakarta: Ghalia Indonesia.

Parvathy, V \& Pillai, Renjith R. (2015). Impact of life skills education on adolescents in rural school. International Journal of Advanced Research, 3 (2), 788-794.

Pawito. (2007). Penelitian komunikasi kualitatif. Yogyakarta: LkiS.

Prajapati, R., Sharma, B., \& Sharma, D. (2017). Significance of life skills education. Contemporary Issues in Education Research, 10(1), 1-6.

Said, H. \& Yusof, S. (2015). Life skills in the process of teaching and learning english. Rhetoric Educator: Communication, Composition, Rhetoric, \& Writing eJournal, 
Amirudin, Iqbal Amar Muzaki / JURNAL TARBIYAH 26 (2) (2019) 278-293

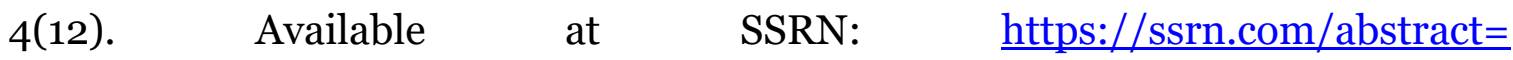
2574696 or http://dx.doi.org/10.2139/ssrn.2574696.

Satori, D. (2002). Implementasi life skill dalam konteks pendidikan di sekolah. Jurnal Pendidikan dan Kebudayaan, 8(034), 25-37.

Sukmadinata, N. S. (2013). Metode penelitian pendidikan. Bandung: Remaja Rosdakarya.

Tashakkori, A. \& Teddlie, C. (2010). Mixed methodology: Mengkombinasikan pendekatan kualitatif dan kuantitatif. Yogyakarta: Pustaka Pelajar.

Wahyuni, S. \& Indrasari, D. Y. (2017). Implementasi pendidikan life skill di SMK Negeri 1 Bondowoso. Jurnal Edukasi, IV(1), 24-29.

Weichold, K., \& Blumenthal, A. (2016). Long-term effects of the life skills program IPSY on substance use: Results of a 4.5-year longitudinal study. Prevention

Science, 17(1), 13-23. 